Article

\title{
Gelam Honey Has a Protective Effect against Lipopolysaccharide (LPS)-Induced Organ Failure
}

\section{Mustafa Kassim $^{1{ }^{*}}$, Marzida Mansor ${ }^{1}$, Nazeh Al-Abd ${ }^{2}$ and Kamaruddin Mohd Yusoff ${ }^{3}$}

1 Department of Anesthesiology, Faculty of Medicine, University of Malaya, 50603 Kuala Lumpur, Malaysia; E-Mail: marzida@gmail.com

2 Department of Biotechnology, Faculty of Science,University of Malaya, 50603 Kuala Lumpur, Malaysia; E-Mail: nazehali78@yahoo.com

3 Department of Molecular Biology and Genetics, Faculty of Arts and Science, Canik Basari University, Samsun, Turkey; E-Mail: mykamar77@gmail.com

* Author to whom correspondence should be addressed; E-Mail: zoobeadi@yahoo.com; Tel.: +603-79492052; Fax: +603-79553705.

Received: 5 April 2012; in revised form: 4 May 2012 / Accepted: 7 May 2012 /

Published: 23 May 2012

\begin{abstract}
Gelam honey exerts anti-inflammatory and antioxidant activities and is thought to have potent effects in reducing infections and healing wounds. The aim of this study was to investigate the effects of intravenously-injected Gelam honey in protecting organs from lethal doses of lipopolysaccharide (LPS). Six groups of rabbits $(N=6)$ were used in this study. Two groups acted as controls and received only saline and no LPS injections. For the test groups, $1 \mathrm{~mL}$ honey $(500 \mathrm{mg} / \mathrm{kg}$ in saline) was intravenously injected into two groups (treated), while saline $(1 \mathrm{~mL})$ was injected into the other two groups (untreated); after $1 \mathrm{~h}$, all four test groups were intravenously-injected with LPS $(0.5 \mathrm{mg} / \mathrm{kg})$. Eight hours after the LPS injection, blood and organs were collected from three groups (one from each treatment stream) and blood parameters were measured and biochemical tests, histopathology, and myeloperoxidase assessment were performed. For survival rate tests, rabbits from the remaining three groups were monitored over a 2-week period. Treatment with honey showed protective effects on organs through the improvement of organ blood parameters, reduced infiltration of neutrophils, and decreased myeloperoxidase activity. Honey-treated rabbits also showed reduced mortality after LPS injection compared with untreated rabbits. Honey may have a therapeutic effect in protecting organs during inflammatory diseases.
\end{abstract}


Keywords: honey; inflammation; lipopolysaccharide; rabbits; biochemical tests; myeloperoxidase

\section{Introduction}

Honey is a natural, sweet and viscous fluid produced by bees from floral nectar, which comprises more than 400 different chemical compounds [1], including proteins, enzymes, organic acids, mineral salts, vitamins, phenolic acids, flavonoids, free amino acids, and small quantities of volatile compounds [2]. Historically, honey has been used as a treatment for a broad spectrum of injuries, including wounds, burns and ulcers [3,4]. Honey has also been reported to stimulate the immune system (monocytes, neutrophils) [5-7]. It also clears infection by boosting the immune system, exerting anti-inflammatory and antioxidant activities, and stimulating cell growth [8]. Gelam honey inhibits nitric oxide (NO) and cytokine release both in vitro and in vivo [9,10].

Lipopolysaccharide (LPS) stimulates innate immune responses that mediate the cellular release of NO and various proinflammatory cytokines and chemokines, as well as inducing macrophage migration and contributing to the pathogenesis of sepsis [11]. Injection of animals with high doses of LPS causes multiple organ failure, characterized by circulatory failure, systemic hypotension, hypo-reactivity to vasoconstrictors, subsequent problems with organ perfusion and the development of functional abnormalities [12], which reflect systemic inflammatory response syndrome and septic shock, rather than endotoxin-induced failure of lung, liver, and renal tissues [13].

Sepsis is the leading cause of death worldwide, with more than 750,000 cases of sepsis diagnosed annually and mortality rates ranging from 30 to $60 \%$; this systemic inflammation accounts for approximately 200,000 deaths per year in the US alone [14]. Sepsis causes endothelial injury and neutrophil infiltration into tissues, leading to local injury, disturbed capillary blood flow and enhanced microvascular permeability, disseminated intravascular coagulation, circulatory collapse, hypoxia and, ultimately, multiple organ failure [15]. The aim of the current study was to investigate whether intravenous injection of honey can protect organs from lethal doses of LPS that induce sepsis in rabbits.

\section{Results}

\subsection{Effect of Gelam Honey on Biochemical and Hematological Tests, Histopathology, and MPO Activity}

Intravenous injection of honey resulted in potent protection against a lethal dose of LPS as evidenced by improved liver, kidney, cardiac and lipid profiles. Compared to the untreated group, the honey-treated group showed significant reductions in the levels of alanine transaminase (ALT), aspartate aminotransferase (AST), $\gamma$-glutamyltransferase $(\gamma$-GT), alkaline phosphatase (ALP), cholesterol, triglycerides, creatine kinase, creatinine, urea and amylase. Moreover, the honey-treated group showed higher RBC, WBC and thrombocyte counts than the untreated group (Table 1). Arterial blood gases and $\mathrm{pH}$ values were determined for all groups (Table 1). The honey-treated group showed mild respiratory alkalosis, while in the untreated group, the arterial blood $\mathrm{pH}$ was closer to acidosis. Blood $\mathrm{pCO}_{2}$ was lowered by LPS injection, but to the same level in the honey-treated group and 
untreated group, indicating that honey injection did not prevent the reduction in $\mathrm{pCO}_{2}$. $\mathrm{Blood} \mathrm{HCO}_{3}$ and $\mathrm{PO}_{2}$ were higher in the honey-treated group than in the untreated group. There was clear evidence of hypoxia in the untreated group, as shown by the reduction in the $\mathrm{pO}_{2}$ value (Table 1). Neutrophil infiltration was reduced in the treated group; however, MPO activity in the honey-treated group was significantly lower than that in the untreated group (Figure 1). In addition, more histopathological changes were observed in the untreated group, as evidenced by cellular infiltration of the lungs (Figure 2). Finally, $66.7 \%$ of rabbits in the untreated group died compared with $33.3 \%$ in the treated group (Figure 3). Survival rates were monitored over a 2-week period.

Figure 1. Effect of honey on neutrophil infiltration into lung tissues induced by a lethal dose of lipopolysaccharide (LPS). Myeloperoxidase (MPO) activity was measured in all groups ( $n=6$ per group) $8 \mathrm{~h}$ after LPS injection. MPO activity was significantly higher in the untreated (saline + LPS $0.5 \mathrm{mg} / \mathrm{kg}$ ) group than in the treated (honey, $500 \mathrm{mg} / \mathrm{kg}+\mathrm{LPS}$ $0.5 \mathrm{mg} / \mathrm{kg}$ ) group. $* * * P<0.002$.

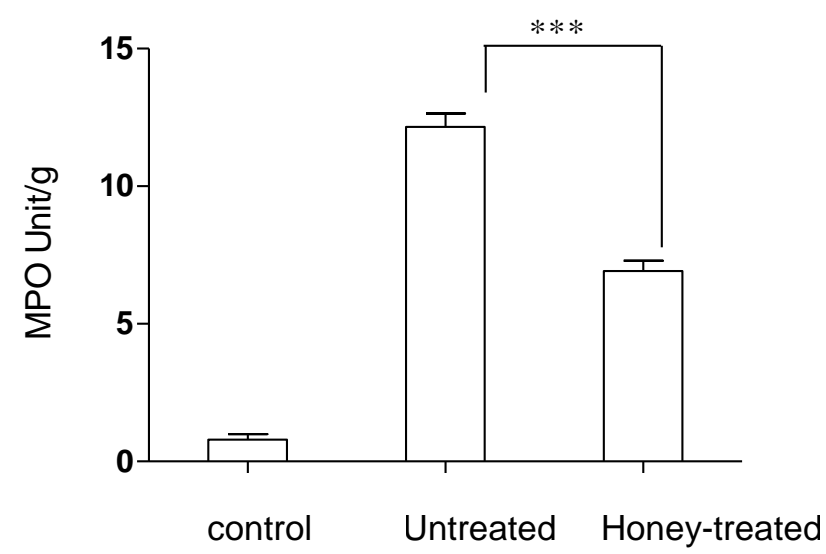

Figure 2. (A) Immune-cell infiltration and tissue damage in the lungs of rabbits from the untreated group $8 \mathrm{~h}$ after LPS injection; (B) Immune-cell infiltration and tissue damage in the lungs of rabbits from the honey-treated group $8 \mathrm{~h}$ after LPS injection; (C) Normal lung tissues in rabbits treated with saline. Hematoxylin and eosin staining; magnification 10x; scale bar, $30 \mu \mathrm{m}$.
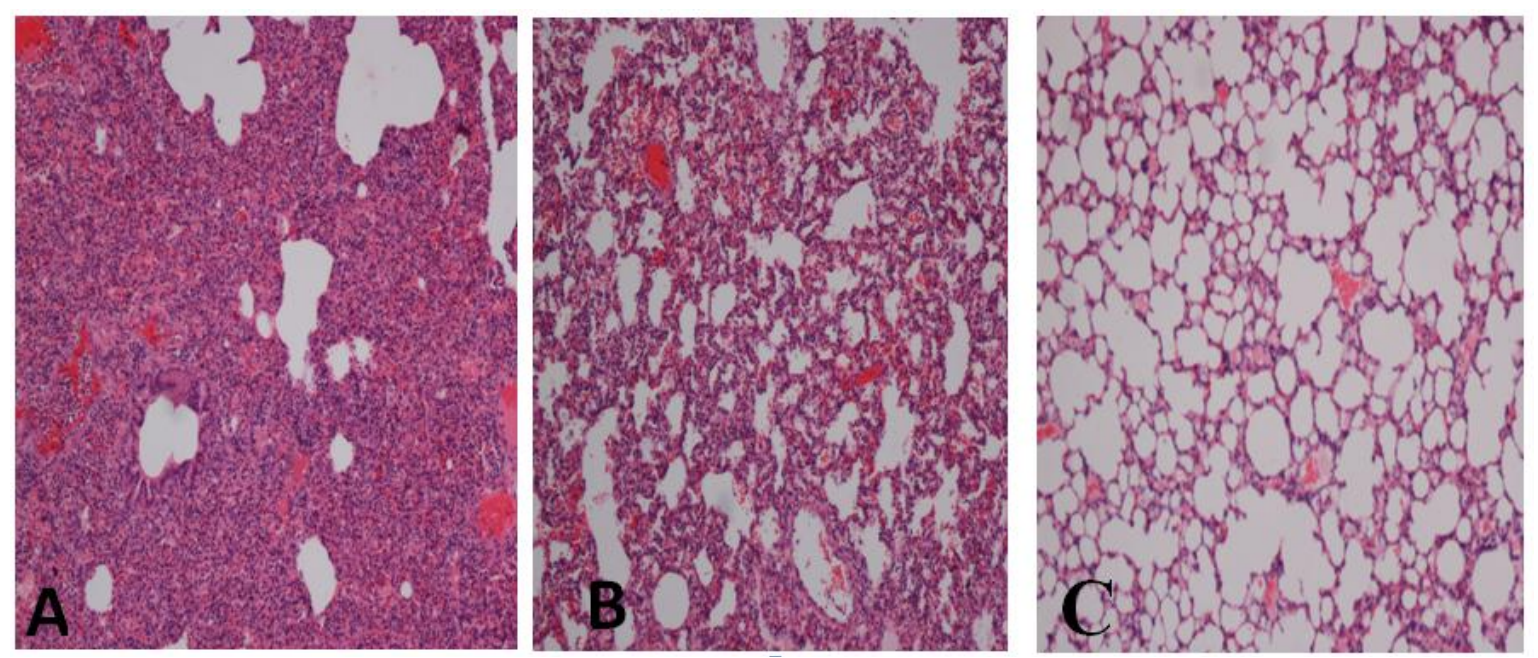
Figure 3. The effect of honey on the survival of rabbits injected with LPS $(0.5 \mathrm{mg} / \mathrm{kg})$. Rabbits in all three groups ( $n=6$ per group) received $1 \mathrm{~mL}$ injections of LPS into the ear vein. The survival rates in the untreated and honey-treated $(60,300$, and $600 \mathrm{mg} / \mathrm{kg}$ ) groups injected with $0.5 \mathrm{mg} / \mathrm{kg}$ LPS are shown as black triangles and black squares, respectively. Control rabbits received saline only (black circles). Honey was administered daily for 3 days after LPS treatment. Kaplan-Meier analysis showed significantly better survival rates in the honey-treated group $(500 \mathrm{mg} / \mathrm{kg}+$ LPS $)$ than in the untreated LPS group (LPS). *** $P<0.005$.

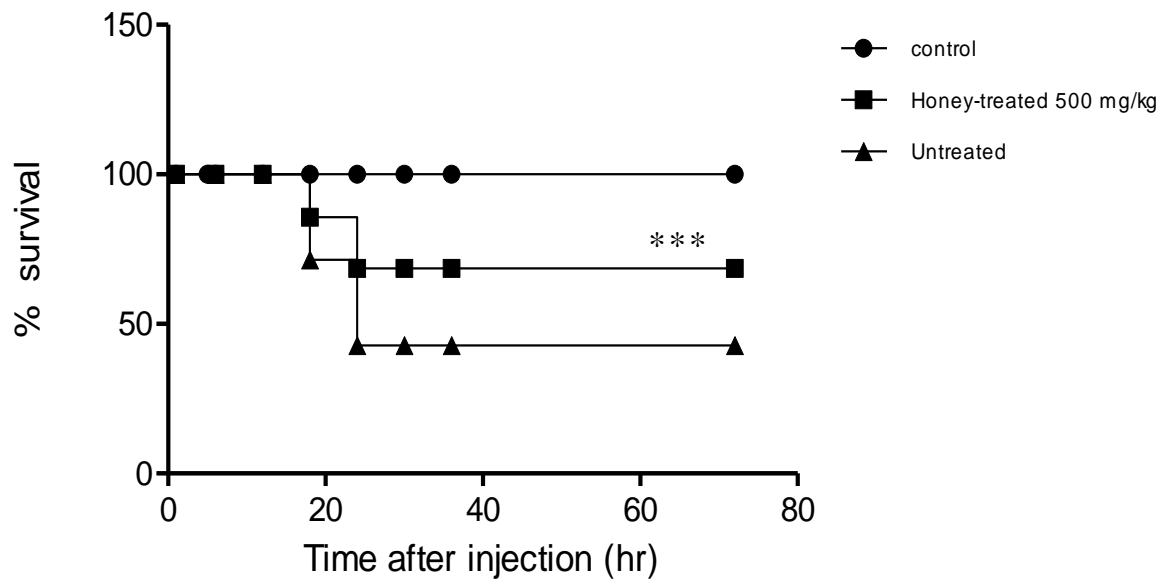

Table 1. Assessment of organ damage in the control group and in honey-treated and untreated groups given a single intravenous injection of lipopolysaccharide.

\begin{tabular}{|c|c|c|c|}
\hline Parameter & Normal Rabbits $(N=6)$ & Untreated $(N=6)$ & Honey-treated $(N=6)$ \\
\hline Urea (mmol/L) & $5.85 \pm 0.20$ & $55.85 \pm 2.5$ & $10.5 \pm 0.23^{a}$ \\
\hline Creatinine (mmol/L) & $83.71 \pm 2.5$ & $154 \pm 6.16$ & $72 \pm 2.87^{\mathrm{a}}$ \\
\hline ALT (IU/L) & $54.125 \pm 1.8$ & $108.75 \pm 3.6$ & $78.75 \pm 1.98^{a}$ \\
\hline AST (IU/L) & $27.75 \pm 0.9$ & $577.33 \pm 19.2$ & $231.5 \pm 7.6^{\mathrm{a}}$ \\
\hline ALP (IU/L) & $131.5 \pm 4.1$ & $542.75 \pm 15.5$ & $308.75 \pm 11.4^{\mathrm{a}}$ \\
\hline GGT (IU/L) & $10 \pm 0.32$ & $38.4 \pm 0.6$ & $25 \pm 1.7^{\mathrm{b}}$ \\
\hline Triglyceride (mmol/L) & $0.885 \pm 0.03$ & $10.434 \pm 0.4$ & $2.47 \pm 0.13^{\mathrm{a}}$ \\
\hline Total cholesterol (mmol/L) & $1.1125 \pm 0.04$ & $3.16 \pm 0.1$ & $1.8 \pm 0.08^{\mathrm{c}}$ \\
\hline HDL (mmol/L) & $0.65 \pm 0.03$ & $0.25 \pm 0.006$ & $0.545 \pm 0.02^{b}$ \\
\hline LDL (mmol/L) & $0.202 \pm 0.005$ & $0.45 \pm 0.01$ & $0.32 \pm 0.012$ \\
\hline Creatine kinase (IU/L) & $1327.4 \pm 5.3$ & $2168.3 \pm 34$ & $998.6 \pm 26.8^{a}$ \\
\hline $\mathrm{pH}(\mathrm{KPa})$ & $7.38 \pm 0.3$ & $7.36 \pm 0.3$ & $7.5 \pm 0.27^{b}$ \\
\hline $\mathrm{pCO}_{2}(\mathrm{KPa})$ & $4.3 \pm 0.17$ & $3 \pm 0.12$ & $3 \pm 0.12$ \\
\hline $\mathrm{pO}_{2}(\mathrm{KPa})$ & $16.21 \pm 0.53$ & $7.65 \pm 0.23$ & $19.3 \pm 0.77^{\mathrm{b}}$ \\
\hline $\mathrm{HCO}_{3}(\mathrm{mmol} / \mathrm{L})$ & $19 \pm 0.71$ & $15 \pm 0.51$ & $19 \pm 0.54^{\mathrm{a}}$ \\
\hline Platelet (10e9/L) & $194.3 \pm 6.4$ & $144.5 \pm 4.3$ & $183.4 \pm 7.6^{\mathrm{b}}$ \\
\hline Amylase (IU/L) & $181.3 \pm 7.2$ & $215.5 \pm 6.2$ & $180 \pm 5.2^{b}$ \\
\hline $\mathrm{RBC}(10 \mathrm{e} 12 / \mathrm{L}$ & $9.27 \pm 0.31$ & $4.83 \pm 0.15$ & $8.3475 \pm 0.32^{\mathrm{a}}$ \\
\hline WBC (10e9/L) & $15 \pm 0.6$ & $6.05 \pm 0.25$ & $11.65 \pm 0.36^{\mathrm{a}}$ \\
\hline
\end{tabular}

${ }^{\mathrm{a}} P<0.001$; significant effect of untreated group $v s$. honey-treated group; ${ }^{\mathrm{b}} P<0.003$; significant effect of untreated group $v s$. honey-treated group; ${ }^{\mathrm{c}} P<0.005$; significant effect of untreated group $v s$. honey-treated group. 


\section{Discussion}

Previous studies have shown that honey has antioxidant, antimicrobial, and anti-inflammatory properties [16]. This study identified a protective role for honey against systemic damage induced by lethal doses of LPS in a rabbit model. These effects were evidenced by decreased blood chemistry parameters of organ dysfunction, decreased cellular infiltration into the tissues, and decreased mortality. To the best of our knowledge, this is the first study showing that honey can protect organs from lethal doses of LPS. The results indicate that honey can counteract the effects of LPS, which is a compound that can lead to organ and multi-organ failure.

When immune responses are insufficient, infections can lead to sepsis [17]. Many studies report that sepsis is a complicated pathophysiological and immunological process that causes alterations in the structure and characteristics of blood cells and tissues, leading to multi-organ failure. Lethal doses of LPS in animals induce a variety of organ and systemic changes that lead to organ failure and, ultimately, to death $[18,19]$. Previous studies have shown that the acute exposure of rabbits to LPS is associated with necrosis in organs such as the lungs and liver. The presence of polymorphonuclear leukocytes (PMNLs) was noted in association with necrosis in the lung and liver as well as an apoptotic cellular appearance in the LPS group. In addition, LPS stimulates the production of many cellular substances, such as cytokines, NO, vasoactive peptides, pro-coagulant factors, and prostaglandins, both in vitro and in vivo [15]. Earlier reports indicate that LPS and cytokines, such as TNF- $\alpha$ and IL-1 $\beta$, induce apoptotic necrosis in cells and tissues [20,21]. Furthermore, LPS activates $\mathrm{NF}-\kappa \mathrm{B}$, which activates many mediators including pro- and anti-inflammatory cytokines such as TNF- $\alpha$,IL-1 $\beta$, IL6 and IL-10 [22]. These cytokines enhance vascular permeability, stimulate the expression of adhesion molecules on endothelial cells, and induce infiltration of cells from the blood to tissues [23]. Sepsis-induced acute lung injury is a major clinical problem with significant morbidity and mortality [24-26]. PMNLs are thought to contribute significantly to the pathophysiologic features of acute lung injury [27-31]. A pathological hallmark of acute lung injury is subsequent tissue infiltration of neutrophils and pulmonary microvascular sequestration [32,33]. Enhanced pulmonary neutrophil sequestration and infiltration during sepsis changes the neutrophil profile by increasing neutrophil surface expression and activating cell-cell adhesion molecules, and enhancing the release of soluble mediators, production of cytokines, and generation of reactive oxygen species, NO, and $\mathrm{ONOO}^{-}$[34-38]. Acute lung injury is characterized by increased MPO activity, a marker of neutrophil infiltration, increased expression and activity of cytokines and iNOS, high-protein pulmonary edema, and oxidant stress [31,39]. Pulmonary microvascular neutrophil sequestration and tissue infiltration are hallmarks of the pathogenesis of acute lung injury [33,40,41]. The present study is in agreement with previous studies showing that sepsis induces changes in pulmonary microvascular neutrophil sequestration and alveolar neutrophil infiltration, [34-36,42] as clearly shown in the untreated group but not in the honey-treated group (Figures 1 and 2). In addition, honey treatment decreased lung injury by inhibiting MPO activity. Therefore, as reported in our previous studies, honey may decrease lung injury through systemic inhibition of cytokines such as $\mathrm{PGE}_{2}$ and $\mathrm{NO}[9,10]$.

In this study, the reductions in $\mathrm{RBC}, \mathrm{WBC}$, and platelet counts observed in the untreated group confirm those seen in earlier reports $[43,44]$. Treatment with honey significantly attenuated the severe reductions in blood counts (WBC and $\mathrm{RBC}$ ) and thrombocytopenia, suggesting that honey has a 
protective role against sepsis-induced disseminated intravascular coagulation. LPS causes disseminated intravascular coagulation, which is associated with coagulation disorders and loss of platelets. In the liver, LPS causes increases in AST, ALT, $\gamma$-GT, and lipid profiles [43,45-49], which are all markers of hepatic damage [44,49,50]. Our results confirm that sepsis caused liver failure, as shown by significantly elevated serum levels of AST, ALP, and $\gamma$-GT in the untreated group; honey inhibited these increases. Improved liver function tests after honey treatment indicate that honey may potentially protect liver cells from sepsis. Lipid profiles showed that cholesterol, triglycerides, and LDL levels were significantly increased in the LPS-induced untreated sepsis group but not in the honey-treated group. However, the HDL levels were significantly lower in the untreated group. Injection of LPS into animals induces renal dysfunction characterized by increased blood urea nitrogen and plasma creatinine levels [45,51]. Urea nitrogen and plasma creatinine levels were increased by LPS injection, but were lower in the honey-treated group than in the untreated group. Both our previous studies and the above results show that LPS increased the levels of hepatic damage markers, modified lipid metabolism, and increased lipid profiles, hematological values, and renal dysfunction [52]. Our results also show that Gelam honey protects organs from immune responses induced by lethal doses of LPS. Our previous study showed that Gelam honey contains many phenolic compounds with antioxidant and anti-inflammatory activity. In addition, its inhibitory effect on cytokines (TNF- $\alpha$, IL-1 $\beta$, and IL-10), high-mobility group protein 1 (HMG-1), and NO both in vitro and in vivo were studied $[9,10,53]$. Gelam honey also showed potent induction of HO-1, a molecule related to oxidative stress [53]. These activities, including the inhibition of cytokines and NO during severe sepsis, suggest that honey may be useful for the treatment of sepsis. The phenolic compounds in Gelam honey play a role in protecting tissues from LPS and free radicals due to their antioxidant activity, such as scavenging oxygen radicals, NO, and lipid radicals [54], and preventing cancer and various inflammatory disorders, such as arthritis and septic shock induced by endotoxemia [55-58]. The beneficial effects of honey, which include preventing histological changes and hypoxia in the organs of rabbits treated with LPS, may be directly related to its antioxidant activity, or indirectly related to the inhibition of PMNL chemotaxis, thereby preventing the production of the chemotactic agents implicated in tissue damage. We showed previously that Gelam honey has potent antioxidant activity and inhibits mediators of inflammation, such as cytokines, NO and PGE2 [9,10,53]. Allergic reactions constitute a potentially serious contraindication for injecting people with honey because honey contains bee-secreted and plant pollenderived proteins that are known to induce allergic reactions [59].

\section{Experimental Section}

\subsection{Preparation of Honey}

Malaysian Gelam honey (Melaleuca spp.) was purchased from the department of Agriculture, Batu Pahat, Johor, Malaysia, and sent to Malaysian Nuclear Agency for sterilization using a Cobalt-60 source (Model JS10000). Honey was mixed with saline and filtered through a $0.20 \mu \mathrm{m}$ syringe filter before injection. 


\subsection{Animals}

Mice Balb/c mice (6-7 weeks of age) and New Zealand white male rabbits weighing $25 \mathrm{~g}$ and $2 \mathrm{~kg}$, respectively, were kept in individual cages under standard conditions ( $12 \mathrm{~h}$ light and $12 \mathrm{~h}$ dark conditions); water and chow diet were available ad libitum. The study was carried out in accordance with the University of Malaya Animal Ethics Committee guidelines for animal experimentation and followed the approved protocols outlined in the project license (ANES/14/07/2010/MKAK (R)).

\subsection{Toxicity Tests}

The toxicity of Gelam honey was evaluated in mice $(n=8)$ for 1 month prior to the study. Four different doses of honey $(10,60,300$, and $600 \mathrm{mg} / \mathrm{kg}$ diluted in saline) were administered daily by injection into the tail vein (final volume, $100 \mu \mathrm{L}$ ). The control group received a similar volume of saline. Mice were observed for $3 \mathrm{~h}$ after injection. Symptoms and mortality were recorded for all groups. At the end of the study, all mice were sacrificed, and blood and organs were collected. Compared with the control group, the treated groups showed no abnormalities on biochemical and histopathological analysis of the liver, lungs, and kidneys (data not shown).

\subsection{Induction of an Immune Response in Rabbits by LPS Stimulation and Treatment with Honey}

New Zealand white male rabbits were divided into six groups $(N=6)$ of six animals $(n=6)$ and each group was treated as described below. An immune response was induced in four groups by intravenous injection of $0.5 \mathrm{mg} / \mathrm{kg}$ LPS (B: 0111; Sigma, St. Louis, MO, USA) diluted in saline. One hour before LPS injection, honey ( $500 \mathrm{mg} / \mathrm{kg}$ diluted in saline) was injected into the rabbits from two groups (treated group), while saline was injected into the rabbits from another two groups (untreated groups). The two remaining groups acted as negative controls and were given saline only and no LPS. All doses were administered in a final volume of $1 \mathrm{~mL}$ and were mixed immediately prior to injection. Three groups, one from each treatment stream, were used for biochemical and histopathological studies and assessment of myeloperoxidase (MPO) activity as described below, while the remaining three groups were used to assess survival rates. Survival was monitored every $12 \mathrm{~h}$ for 15 days.

\subsection{Biochemical Analysis}

Blood samples were collected from the ears of rabbits after $8 \mathrm{~h}$ of LPS injection. Serum was separated by centrifugation at $3000 \times \mathrm{g}$ at $23{ }^{\circ} \mathrm{C}$, and hematological and biochemistry analysis were performed using an automated hematology cell counter analyzer (Sysmex XE-2100, Sysmex America, Inc.) and Advia 2400 Chemistry System (Siemen, Eschborn, Germany), respectively, in the clinical diagnostic laboratory at University of Malaya Medical Center. Biochemical analyses included measurement of glucose, liver, and kidney functions. The parameters used for hematological analysis were red blood cell count (RBC), white blood cell count (WBC), and platelet counts. Arterial blood samples were collected to measure $\mathrm{pH}, \mathrm{pO}_{2}, \mathrm{pCO}_{2}$, and $\mathrm{HCO}_{3}$ using a blood gas analyser at the same time as the other biomedical tests were performed. 


\subsection{Myeloperoxidase Assay}

Neutrophil infiltration into the lungs was monitored by measuring MPO activity as previously reported [60]. Briefly, tissue specimens were homogenized at $50 \mathrm{mg} / \mathrm{mL}$ in PBS (50 mM, pH 6.0) containing $0.5 \%$ exadecyltrimethylammonium bromide (Sigma-Aldrich). Samples were freeze-thawed three times and centrifuged at 13,000 rpm for $20 \mathrm{~min}$. The supernatants were diluted 1:30 in assay buffer (50 mM PBS pH 6.0 containing $0.167 \mathrm{mg} / \mathrm{mL}$ o-dianisidine; (Sigma-Aldrich) and 0.0005\% $\mathrm{H}_{2} \mathrm{O}_{2}$ ), and the colorimetric reaction was measured at $450 \mathrm{~nm}$ for between 1 and 3 min in a spectrophotometer (Microplate reader, Model 680, Life Science Research, Bio-Rad). MPO activity/g of wet tissue was calculated as follows: MPO activity (U/g wet tissue) $=($ A450) (13.5)/tissue weight $(\mathrm{g})$, where A450 is the change in the absorbance of $450 \mathrm{~nm}$ light between 1 and 3 min after the initiation of the reaction. The coefficient 13.5 was empirically determined such that $1 \mathrm{U}$ MPO activity corresponded to the amount of enzyme that reduced $1 \mu \mathrm{mol}$ peroxide/min.

\subsection{Histopathology}

Liver, lung, heart, and kidney tissues were fixed in $10 \%$ formalin after the organs were dehydrated using graded ethanol solutions, cleared with xylene, paraffin embedded, sectioned, and stained with hematoxylin and eosin. Pathological changes were evaluated under a light microscope by a pathologist.

\subsection{Statistical Analysis}

All data are expressed as the mean \pm confidence interval. Data were analysed using GraphPad prism statistical software (San Diego, CA, USA) for non-parametric analysis of variance. Kaplan-Meier analysis was used to compare survival rates. Differences were considered statistically significant at $P<0.05$.

\section{Conclusions}

In summary, Gelam honey protects organs from lethal doses of LPS by improving organ functions, reducing infiltration by PMNs that cause tissue damage, reducing MPO activity and increasing the survival rate.

\section{Acknowledgments}

This work was supported in part by grants (No. PV009/2011B, RG031/09HTM, and RG225/10HTM) from the University of Malaya.

\section{Conflict of Interest}

The authors declare no conflict of interest. 


\section{References}

1. Lazaridou, A.; Biliaderis, C.G.; Bacandritsos, N.; Sabatini, A.G. Composition, thermal and rheological behaviour of selected greek honeys. J. Food Eng. 2004, 64, 9-21.

2. Gheldof, N.; Wang, X.H.; Engeseth, N.J. Buckwheat honey increases serum antioxidant capacity in humans. J. Agric. Food Chem. 2003, 51, 1500-1505.

3. White, R. The benefits of honey in wound management. Nurs. Stand. 2005, 20, 57-64; quiz 66.

4. Molan, P.C. The evidence supporting the use of honey as a wound dressing. Int. J. Low. Extrem. Wounds 2006, 5, 40-54.

5. Tonks, A.J.; Dudley, E.; Porter, N.G.; Parton, J.; Brazier, J.; Smith, E.L.; Tonks, A. A 5.8-kda component of manuka honey stimulates immune cells via TLR4. J. Leukoc. Biol. 2007, 82, 1147-1155.

6. Molan, P.C. Potential of honey in the treatment of wounds and burns. Am. J. Clin. Dermatol. 2001, 2, 13-19.

7. Majtan, J.; Kovacova, E.; Bilikova, K.; Simuth, J. The immunostimulatory effect of the recombinant apalbumin 1-major honeybee royal jelly protein-on tnfalpha release. Int. Immunopharmacol. 2006, 6, 269-278.

8. Leong, A.G.; Herst, P.M.; Harper, J.L. Indigenous new zealand honeys exhibit multiple anti-inflammatory activities. Innate Immun. 2011, doi:10.1177/1753425911422263.

9. Kassim, M.; Achoui, M.; Mansor, M.; Yusoff, K.M. The inhibitory effects of gelam honey and its extracts on nitric oxide and prostaglandin $\mathrm{E}(2)$ in inflammatory tissues. Fitoterapia 2010, 81, 1196-1201.

10. Kassim, M.; Achoui, M.; Mustafa, M.R.; Mohd, M.A.; Yusoff, K.M. Ellagic acid, phenolic acids, and flavonoids in malaysian honey extracts demonstrate in vitro anti-inflammatory activity. Nutr. Res. 2010, 30, 650-659.

11. Wang, H.; Li, W.; Li, J.; Rendon-Mitchell, B.; Ochani, M.; Ashok, M.; Yang, L.; Yang, H.; Tracey, K.J.; Wang, P.; et al. The aqueous extract of a popular herbal nutrient supplement, angelica sinensis, protects mice against lethal endotoxemia and sepsis. J. Nutr. 2006, 136, 360-365.

12. Bone, R.C.; Grodzin, C.J.; Balk, R.A. Sepsis: A new hypothesis for pathogenesis of the disease process. Chest 1997, 112, 235-243.

13. Bohlinger, I.; Leist, M.; Gantner, F.; Angermuller, S.; Tiegs, G.; Wendel, A. DNA fragmentation in mouse organs during endotoxic shock. Am. J. Pathol. 1996, 149, 1381-1393.

14. Angus, D.C.; Linde-Zwirble, W.T.; Lidicker, J.; Clermont, G.; Carcillo, J.; Pinsky, M.R. Epidemiology of severe sepsis in the united states: Analysis of incidence, outcome, and associated costs of care. Crit. Care Med. 2001, 29, 1303-1310.

15. Cohen, J. The immunopathogenesis of sepsis. Nature 2002, 420, 885-891.

16. Al-Jabri, A.A. Honey, milk and antibiotics. Afr. J. Biotechnol. 2005, 4, 1580-1587.

17. Molan, P.C. The potential of honey to promote oral wellness. Gen. Dent. 2001, 49, 584-589.

18. Van Deventer, S.J.; ten Cate, J.W.; Tytgat, G.N. Intestinal endotoxemia. Clinical significance. Gastroenterology 1988, 94, 825-831. 
19. Wenzel, R.P.; Pinsky, M.R.; Ulevitch, R.J.; Young, L. Current understanding of sepsis. Clin. Infect. Dis. 1996, 22, 407-412.

20. Tracey, K.J.; Lowry, S.F.; Beutler, B.; Cerami, A.; Albert, J.D.; Shires, G.T. Cachectin/tumor necrosis factor mediates changes of skeletal muscle plasma membrane potential. J. Exp. Med. 1986, 164, 1368-1373.

21. Schafer, T.; Scheuer, C.; Roemer, K.; Menger, M.D.; Vollmar, B. Inhibition of p53 protects liver tissue against endotoxin-induced apoptotic and necrotic cell death. FASEB J. 2003, 17, 660-667.

22. Essani, N.A.; McGuire, G.M.; Manning, A.M.; Jaeschke, H. Endotoxin-induced activation of the nuclear transcription factor kappa B and expression of E-selectin messenger RNA in hepatocytes, Kupffer cells, and endothelial cells in vivo. J. Immunol. 1996, 156, 2956-2963.

23. Dustin, M.L.; Springer, T.A. Role of lymphocyte adhesion receptors in transient interactions and cell locomotion. Annu. Rev. Immunol. 1991, 9, 27-66.

24. Luce, J.M. Acute lung injury and the acute respiratory distress syndrome. Crit. Care Med. 1998, 26, 369-376.

25. Vincent, J.L.; Sakr, Y.; Ranieri, V.M. Epidemiology and outcome of acute respiratory failure in intensive care unit patients. Crit. Care Med. 2003, 31, S296-S299.

26. Bernard, G.R.; Artigas, A.; Brigham, K.L.; Carlet, J.; Falke, K.; Hudson, L.; Lamy, M.; Legall, J.R.; Morris, A.; Spragg, R. The american-european consensus conference on ards. Definitions, mechanisms, relevant outcomes, and clinical trial coordination. Am. J. Respir. Crit. Care Med. 1994, 149, 818-824.

27. Braude, S.; Nolop, K.B.; Hughes, J.M.; Barnes, P.J.; Royston, D. Comparison of lung vascular and epithelial permeability indices in the adult respiratory distress syndrome. Am. Rev. Respir. Dis. 1986, 133, 1002-1005.

28. Patterson, C.E.; Barnard, J.W.; Lafuze, J.E.; Hull, M.T.; Baldwin, S.J.; Rhoades, R.A. The role of activation of neutrophils and microvascular pressure in acute pulmonary edema. Am. Rev. Respir. Dis. 1989, 140, 1052-1062.

29. Tomashefski, J.F., Jr. Pulmonary pathology of the adult respiratory distress syndrome. Clin. Chest Med. 1990, 11, 593-619.

30. Singh, R.; Barden, A.; Mori, T.; Beilin, L. Advanced glycation end-products: A review. Diabetologia 2001, 44, 129-146.

31. Wang, L.F.; Patel, M.; Razavi, H.M.; Weicker, S.; Joseph, M.G.; McCormack, D.G.; Mehta, S. Role of inducible nitric oxide synthase in pulmonary microvascular protein leak in murine sepsis. Am. J. Respir. Crit. Care Med. 2002, 165, 1634-1639.

32. Tate, R.M.; Repine, J.E. Neutrophils and the adult respiratory distress syndrome. Am. Rev. Respir. Dis. 1983, 128, 552-559.

33. Kindt, G.C.; Gadek, J.E.; Weiland, J.E. Initial recruitment of neutrophils to alveolar structures in acute lung injury. J. Appl. Physiol. 1991, 70, 1575-1585.

34. Doerschuk, C.M. Mechanisms of leukocyte sequestration in inflamed lungs. Microcirculation 2001, 8, 71-88.

35. Brown, D.M.; Drost, E.; Donaldson, K.; MacNee, W. Deformability and $c d 11 / c d 18$ expression of sequestered neutrophils in normal and inflamed lungs. Am. J. Respir. Cell Mol. Biol. 1995, 13, $531-539$. 
36. Skoutelis, A.T.; Kaleridis, V.; Athanassiou, G.M.; Kokkinis, K.I.; Missirlis, Y.F.; Bassaris, H.P. Neutrophil deformability in patients with sepsis, septic shock, and adult respiratory distress syndrome. Crit. Care Med. 2000, 28, 2355-2359.

37. Goode, H.F.; Webster, N.R. Free radicals and antioxidants in sepsis. Crit. Care Med. 1993, 21, 1770-1776.

38. Novelli, G.P. Role of free radicals in septic shock. J. Physiol. Pharmacol. 1997, 48, 517-527.

39. Razavi, H.M.; Werhun, R.; Scott, J.A.; Weicker, S.; Wang, L.F.; McCormack, D.G.; Mehta, S. Effects of inhaled nitric oxide in a mouse model of sepsis-induced acute lung injury. Crit. Care Med. 2002, 30, 868-873.

40. Hogg, J.C.; Doerschuk, C.M. Leukocyte traffic in the lung. Annu. Rev. Physiol. 1995, 57, 97-114.

41. Downey, G.P.; Fialkow, L.; Fukushima, T. Initial interaction of leukocytes within the microvasculature: Deformability, adhesion, and transmigration. New Horiz. 1995, 3, 219-228.

42. Razavi, H.M.; Wang, L.F.; Weicker, S.; Rohan, M.; Law, C.; McCormack, D.G.; Mehta, S. Pulmonary neutrophil infiltration in murine sepsis: Role of inducible nitric oxide synthase. Am. J. Respir. Crit. Care Med. 2004, 170, 227-233.

43. Aoki, Y.; Ota, M.; Katsuura, Y.; Komoriya, K.; Nakagaki, T. Effect of activated human protein $\mathrm{c}$ on disseminated intravascular coagulation induced by lipopolysaccharide in rats. Arzneimittelforschung 2000, 50, 809-815.

44. Chiou, W.F.; Ko, H.C.; Chen, C.F.; Chou, C.J. Evodia rutaecarpa protects against circulation failure and organ dysfunction in endotoxaemic rats through modulating nitric oxide release. J. Pharm. Pharmacol. 2002, 54, 1399-1405.

45. Chen, C.P.; Yokozawa, T.; Kitani, K. Beneficial effects of sanguisorbae radix in renal dysfunction caused by endotoxin in vivo. Biol. Pharm. Bull. 1999, 22, 1327-1330.

46. Cunha, F.Q.; Assreuy, J.; Moncada, S.; Liew, F.Y. Phagocytosis and induction of nitric oxide synthase in murine macrophages. Immunology 1993, 79, 408-411.

47. Deaciuc, I.V.; D’Souza, N.B.; de Villiers, W.J.; Burikhanov, R.; Sarphie, T.G.; Hill, D.B.; McClain, C.J. Inhibition of caspases in vivo protects the rat liver against alcohol-induced sensitization to bacterial lipopolysaccharide. Alcohol. Clin. Exp. Res. 2001, 25, 935-943.

48. Hong, K.W.; Kim, K.E.; Rhim, B.Y.; Lee, W.S.; Kim, C.D. Effect of rebamipide on liver damage and increased tumor necrosis factor in a rat model of endotoxin shock. Dig. Dis. Sci. 1998, 43, 154S-159S.

49. Jiang, J.; Chen, H.; Diao, Y.; Tian, K.; Zhu, P.; Wang, Z. Distribution of endotoxins in tissues and circulation and its effects following hemorrhagic shock. Chin. Med. J. (Engl.) 1998, 111, 118-122.

50. Barton, C.C.; Ganey, P.E.; Roth, R.A. Lipopolysaccharide augments aflatoxin B(1)-induced liver injury through neutrophil-dependent and -independent mechanisms. Toxicol. Sci. 2000, 58, 208-215.

51. Wellings, R.P.; Corder, R.; Vane, J.R. Lack of effect of ET antibody or SB 209670 on endotoxin-induced renal failure. J. Cardiovasc. Pharmacol. 1995, 26, S476-S478.

52. Memon, R.A.; Grunfeld, C.; Moser, A.H.; Feingold, K.R. Tumor necrosis factor mediates the effects of endotoxin on cholesterol and triglyceride metabolism in mice. Endocrinology 1993, 132, 2246-2253. 
53. Kassim, M.; Mansor, M.; Achoui, M.; Ong, G.S.Y.; Sekaran, S.D.; Yusoff, K.M. Honey as an immunomodulator during sepsis in animal models. Crit. Care 2009, 13, doi:10.1186/cc8096.

54. Salah, N.; Miller, N.J.; Paganga, G.; Tijburg, L.; Bolwell, G.P.; Rice-Evans, C. Polyphenolic flavanols as scavengers of aqueous phase radicals and as chain-breaking antioxidants. Arch. Biochem. Biophys. 1995, 322, 339-346.

55. Unno, T.; Sakane, I.; Masumizu, T.; Kohno, M.; Kakuda, T. Antioxidant activity of water extracts of lagerstroemia speciosa leaves. Biosci. Biotechnol. Biochem. 1997, 61, 1772-1774.

56. Virgili, F.; Kim, D.; Packer, L. Procyanidins extracted from pine bark protect alpha-tocopherol in ECV 304 endothelial cells challenged by activated raw 264.7 macrophages: Role of nitric oxide and peroxynitrite. Fed. Eur. Biochem. Soc. Lett. 1998, 431, 315-318.

57. Yang, F.; de Villiers, W.J.; McClain, C.J.; Varilek, G.W. Green tea polyphenols block endotoxin-induced tumor necrosis factor-production and lethality in a murine model. J. Nutr. 1998, 128, 2334-2340.

58. Wakabayashi, I. Inhibitory effects of baicalein and wogonin on lipopolysaccharide-induced nitric oxide production in macrophages. Basic Clin. Pharmacol. Toxicol. 1999, 84, 288-291.

59. Bauer, L.; Kohlich, A.; Hirschwehr, R.; Siemann, U.; Ebner, H.; Scheiner, O.; Kraft, D.; Ebner, C. Food allergy to honey: Pollen or bee products? Characterization of allergenic proteins in honey by means of immunoblotting. J. Allergy Clin. Immunol. 1996, 97, 65-73.

60. Bradley, P.P.; Christensen, R.D.; Rothstein, G. Cellular and extracellular myeloperoxidase in pyogenic inflammation. Blood 1982, 60, 618-622.

(C) 2012 by the authors; licensee MDPI, Basel, Switzerland. This article is an open access article distributed under the terms and conditions of the Creative Commons Attribution license (http://creativecommons.org/licenses/by/3.0/). 